\title{
神経科学
}

\section{Light moulds plastic brains}

\section{光は神経系の形成に影響する}

\section{Stefan Thor}

Nature Vol.456 (177-178)/ 13 November 2008

オタマジャクシは、光に照らされると神経伝達物質であるドーパミンを発現するニューロンの数が増加する。動物は、 こうした可塑性によって、環境からの刺激に脳の活動を適合させることができる。

神経系は環境からの刺激入力に順応することが知られてい る。そうした可塑性にかかわっているのは、学習や記憶に みられるような神経回路の変更や、シナプス接合を介した ニューロン間コミュニケーションであって、各種ニューロ ンの数の変化は関与していないと考えられてきた。しかし Nature 2008 年 11 月 13 日号で、Dulcis と Spitzer がこの見 方を覆している ${ }^{1}$ 。彼らは、アフリカッメガエル (Xenopus laevis）のオタマジャクシに光を照射すると、脳内のドーパミ ンを分泌するニューロン（ドーパミン作動性ニューロンとよ ばれる）の数が増え、オタマジャクシはその後の光照射にもつ と迅速に順応できるようになることを明らかにしたのである。 池にいる野生のオタマジャクシを捕まえた経験があるな ら、水槽に入れて 2 時間ほど経つとオタマジャクシの体色が うすくなるのを見て、びっくりしたことがあるかもしれない。 この体色の急速な変化のおかげでオタマジャクシは周囲の背 景に溶け込んで、捕食されるリスクを低減させることができ る。このプロセスは特定の神経回路に制御されている。具体 的にいうと、まず、光によって誘発された信号が、眼からドー パミン作動性ニューロンのある視交叉上核とよばれる脳領域 ヘ伝えられる。次いで信号は、メラニン細胞刺激ホルモンを 分泌して皮膚の色素細胞を刺激するニューロンが存在する、

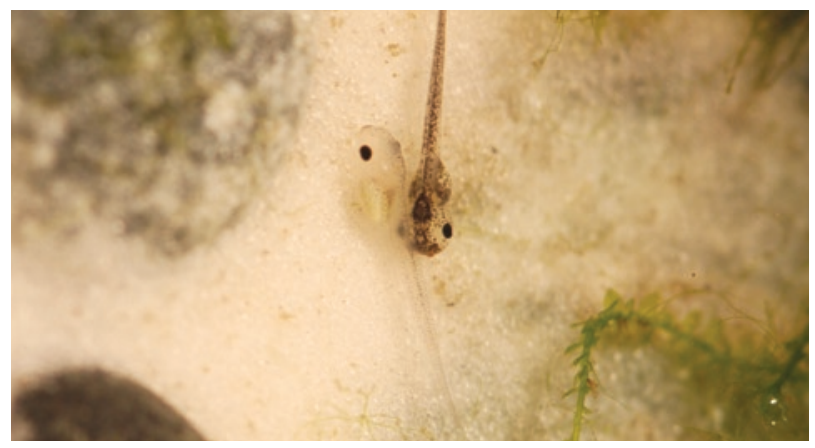

光に照らされて体色がうすくなったアフリカツメガエルのオタマジャクシ (左) と、元の濃い体色のオタマジャクシ (右)。
別の脳領域に伝えられる（図 la)。この伝達は、明暗に応じ た別々の作用を示し、光に応答した眼から視交叉上核への正 の刺激入力は、ドーパミン放出量の増加を引き起こす。この ようにドーパミン量が増えたことが、メラニン細胞刺激ホル モン分泌ニューロンに対する負の刺激入力となって、その結 果このホルモン分泌量が減少し、未梢の皮膚色がうすくなる。

オタマジャクシでは、体色の応答は過去の経験によって変 更される。それは、明るい光に長い時間または繰り返しさら されると、それ以降は体色が以前よりも短時間で光照射に順 応するようになる ${ }^{2}$ ためである。この応答やその基盤にある 回路の変化は詳しく調べられており ${ }^{2-5}$ 、主にシナプス結合 や回路を伝わる信号伝達の段階での可塑性が関与していると 考えられていた。しかし、今回 Dulcis と Spitzer は、この 順応には回路内のドーパミン作動性ニューロンの数の急増も 関係していることを明らかにした ${ }^{1}$ 。

2 人が観察した応答の速度は驚異的なものだった。暗闇 で育てたオタマジャクシに光をたつた 2 時間当てただけで、 視交叉上核にあるドーパミン作動性ニューロンが倍増した のである。そのうえ、新たに出現したこれらのニューロンは、 その後の光照射で体色が急速にうすくなる体色変化過程に 影響しているようだった(図 $1 b)$ 。著者らは、これらのニュー ロンの軸索突起を追跡し、メラニン細胞刺激ホルモンを放 出するニューロンまで突起が伸びていることを見つけた。 次に、特異的な薬剤を使って、もとからあるドーパミン作 動性ニューロンを除去したところ、光への順応が完全に損 なわれた。ところがその後、ドーパミン作動性ニューロン を除去したオタマジャクシに光を照射したところ、薬剤処 理の後に生じたドーパミン作動性ニューロンによって光へ の順応が回復できた。

これらの「新しい」ドーパミン作動性ニューロンはどこか らやってきたのだろうか。既存のニューロンが分泌する神経 伝達物質の種類を変化させた結果なのだろうか。それとも まったく新たに生じたのだろうか。これまでの研究から、哺 


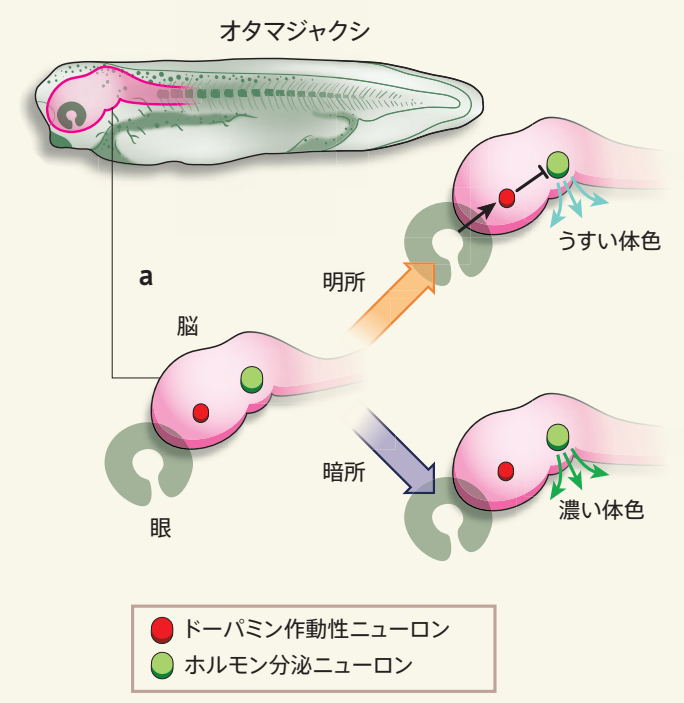

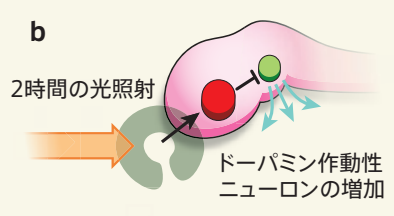
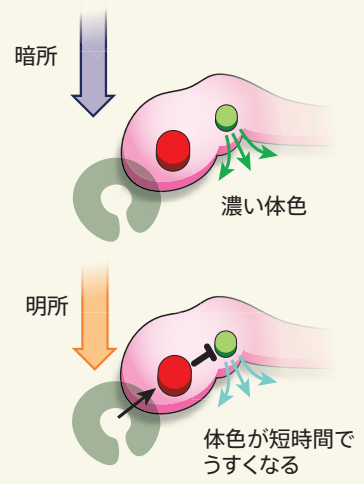

図 1 オタマジャクシの体色変化にかかわる 神経回路の可塑性。a，オタマジャクシは、眼 から脸の視交叉上核にあるドーパミン作動性 ニューロン (赤色) への信号伝達にかかわる 神経回路を用い、周囲の光条件に応じて体 色を調整する。これらのニューロンは、メラ ニン細胞刺激ホルモンを分泌するニューロン (緑色) からのホルモン放出を抑制する。b， Dulcis と Spitzer ${ }^{1}$ は、約 2 時間の光照射で、 オタマジャクシの視交叉上核に新たなドーパミ ン作動性ニューロンが加わることを見つけた。 これを暗条件に戻すと、体色は濃くなる。しか しその後、再び光を照射すると、既存のもの だけでなく新規のドーパミン作動性ニューロン があるおかげで、体色は短時間でうすくなる。 したがって成長中のオタマジャクシでは、新た に加わったドーパミン作動性ニューロンが順応 に好都合な働きをする。
乳類の脳（たとえ成体の脳でも）は絶えず新しいニューロン

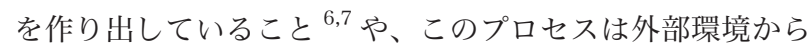
の刺激に応答して増強される可能性があること ${ }^{8-10}$ が明らか になっている。例えば、実験用マウスの成体を刺激の豊富な 環境（回し車や巣材、遊具を備えた大きな飼育ケージ）に置 くと、脳の特定領域にあるニューロン、なかでも空間定位に 重要なニューロンの数が増える ${ }^{10}$ 。同じように、鳴禽では季 節によって、脳の特定領域にニューロンが追加されたり除去 されたりする。これは、脳の構造を適切な季節行動へ適合さ せるように㗢く仕組みの 1 つである ${ }^{11}$ 。しかし、オタマジャ クシの光順応の例で Dulcis と Spitzer は、視交叉上核に新 しい細胞が生じているという証拠を何も見つけられなかっ た。追加のドーパミン作動性ニューロンが短時間で現れるこ とを考えると、この観察結果はおそらく予想できただろう。 追加のニューロンが、わずか 2 時間というかなり短時間の うちに新たに生じることができたとは考えにくい。そうでは なく、別の神経伝達物質を発現していた既存のニューロンが、 新たにドーパミンを同時発現するようになったとみられる。

Dulcis と Spitzer の知見は、外部からの感覚入力が脳内の 特異的な種類のニューロンの数を変化させることで、特異的 な応答を調節するという説を進展させるものだ。これらの ニューロン集団は、刺激入力への生理的応答を制御するのに 関与している。さらに視点を広げると、脳の可塑性が生じう る仕組みは既にいくつか見つかっており、既存のニューロン が追加の神経伝達物質の発現スイッチを入れることができる という 2 人の観察結果は、そうした仕組みのリストに追加 されるものである。このリストにはほかに、ニューロン間コ ミュニケーションの減弱もしくは強化、新しい接続の形成と いったものが含まれ、近年の知見では、特定種類のニュー
ロンが神経系にさらに新規に追加されることも示されてい る ${ }^{6-10}$ 。しかし、Dulcis と Spitzer が今回取り組まなかった 問題がある。それは、彼らが観察した種類の脳の可塑性が、 成長中のオタマジャクシに限られたものなのか、あるいはカ エル成体にも当てはまるのか、そしてさらにいえば哺乳類に も当てはまるのか、という問題である。

ヒトでは、ドーパミンが関与するシグナル伝達カスケー ドの異常は、冬季うつ病として知られる季節性情動障害の 重要な要因だと考えられている ${ }^{12}$ 。これについて今後なさ れるべき分析の 1 つは、陽電子放出断層撮影法 (PET) を 用いて患者を解析することかもしれない。PET はドーパ ミン作動性ニューロンの視覚化によく用いられる技術であ $3^{13}$ 。PET 画像の解像度には限界があるが、日長の季節的 変動や光度の日変化に応答していると思われるドーパミン 作動性ニューロン数の劇的増加は検出できるだろう。神経 伝達物質の産生パターンの変化が関係する脳の可塑性がヒ トにもあるとわかれば、神経疾患の解明や治療に向けて新 たな道が開けるかもしれない。

StefanThor、リンシェーピン大学（スウェーデン）。

1. Dulcis, D. \& Spitzer, N. C. Nature 456, 195-201 (2008)

2. Roubos, E. W. Comp. Biochem. Physiol. 118, 533-550 (1997).

3. Kramer, B. M. R. et al. Microsc. Res. Tech. 54,188-199 (2001).

4. Tuinhof, R. et al. Neuroscience 61, 411-420 (1994).

5. Ubink, R., Tuinhof, R. \& Roubos, E. W. J. Comp. Neurol. 397, 60-68 (1998).

6. Chen, J., Magavi, S. S. P.\&Macklis, J. D. Proc. Natl Acad. Sci. USA 101, 16357-16362 (2004).

7. Magavi, S. S., Leavitt, B. R. \& Macklis, J. D. Nature 405, 951-955 (2000).

8. van Praag, H., Christie, B. R., Sejnowski, T. J. \& Gage, F. H. Proc. Natl Acad. Sci. USA 96, 13427-13431 (1999).

9. van Praag, H. et al. Nature 415, 1030-1034 (2002).

10. Kempermann, G., Gast, D. \& Gage, F. H. Ann. Neurol. 52, 135-143 (2002).

11. Nottebohm, F. Brain Res. Bull. 57, 737-749 (2002).

12. Lam, R. W., Tam, E. M., Grewal, A. \& Yatham, L. N. Neuropsychopharmacology 25 (Suppl.), S97-S101(2001).

13. Perlmutter, J. S. \& Moerlein, S. M. Q. J. Nucl. Med. 43, 140-154 (1999). 